\title{
Whether Gas Plasma Exposure can Inactivate Virus in the Room in Success
}

\section{Hideharu Shintani*}

Chuo University, School of Science, 1-13-27, Kasuga Bunkyo 112-0003 Tokyo, Japan

\section{Abstract}

In Japan, many electric instrument companies attach plasma exposure and they mention that virus in the room can inactivate in success. We need to confirm and evaluate this PR is scientifically correct or not from the standpoint of third party.

\section{Procedure}

One of the electric companies above described is Sharp Co. and their PR cited from their HP is presented in Figure 1. It is in Japanese, so I explain what they mention. Gas plasma exposure produce ions (cation and anion) to bind bacteria and virus. Bound ions then change to radicals and destroy bacteria, virus and allergen and so on. We need to confirm this statement is scientifically correct or not.

As presented in Figure 2, gas plasma simultaneously produce ions,

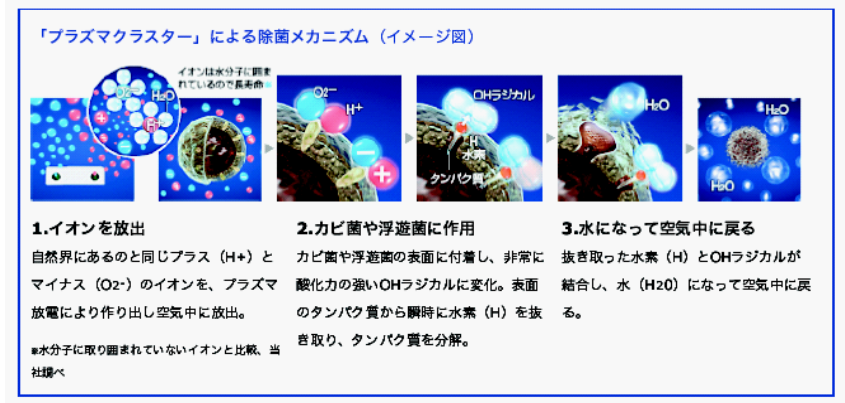

Figure 1: So-called inactivation mechanism by gas plasma proposed by Sharp Co.

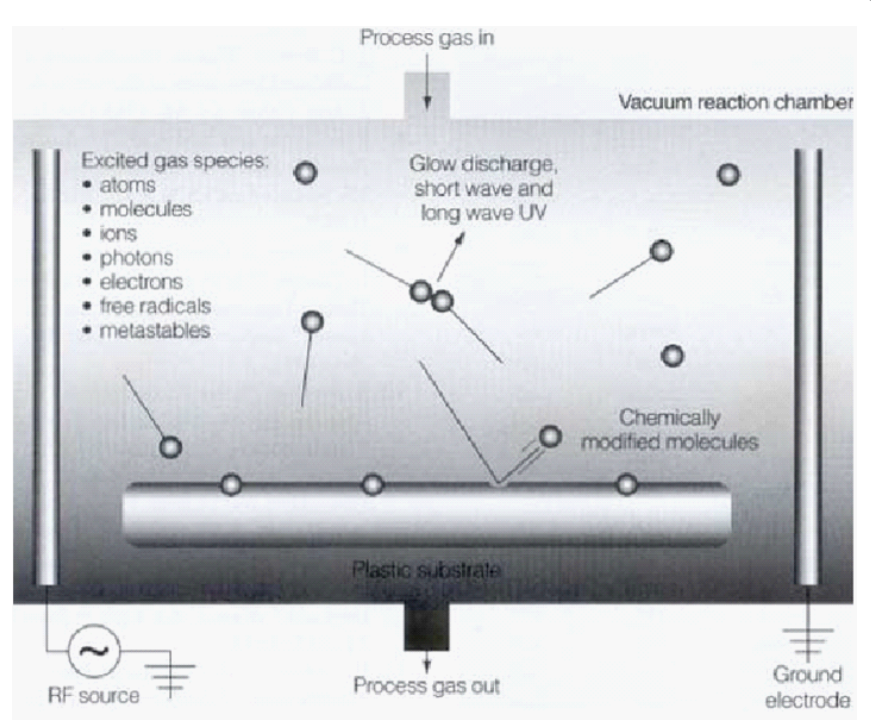

Figure 2: Active species produced from gas plasma exposure. free radicals, metastables and so on. So ions do not change to radicals by gas plasma exposure contrary to Figure 1 .

Gas plasmas attack water and dissociate to $\mathrm{H}$ radical $(\mathrm{H})$ and $\mathrm{OH}$ radical $(\mathrm{OH})$ and $\mathrm{OH}$ radical is 4 times more active than $\mathrm{H}$ radical (Figure 3).

Life period of $\mathrm{OH}$ radical is around $10^{-6}$ to $10^{-9}$ second and the flight distance is around $30 \mathrm{~cm}$ for $10^{-2}$ second, indicating $\mathrm{OH}$ radicals do not flight long length during their life period [1].

There are several reactions related with this subject [1].

Two $\mathrm{OH}$ radicals bind and produce $\mathrm{H}_{2} \mathrm{O}_{2}$ at the kinetic rate of $5 \times 10^{9} / \mathrm{M} / \mathrm{sec}$.

$\mathrm{OH}+\mathrm{OH} \rightarrow \mathrm{H}_{2} \mathrm{O}_{2} \mathrm{k}=5 \times 10^{9} / \mathrm{M} / \mathrm{sec}$

In addition, within the bacteria, spore, there occurs Fenton reaction as bellows;

$$
\begin{aligned}
& \mathrm{Fe}^{2+}+\mathrm{H}_{2} \mathrm{O}_{2} \rightarrow \mathrm{Fe}^{3+}+\mathrm{OH}^{-}+\mathrm{OH} \cdot \mathrm{k}=76 / \mathrm{M} / \mathrm{sec} \\
& \mathrm{Cu}^{+}+\mathrm{H}_{2} \mathrm{O}_{2} \rightarrow \mathrm{Cu}^{2+}+\mathrm{OH}^{-}+\mathrm{OH} \cdot \mathrm{k}=4.7 \times 103 / \mathrm{M} / \mathrm{sec}
\end{aligned}
$$

Even though life period of $\mathrm{OH}$ radical is short, they produced many

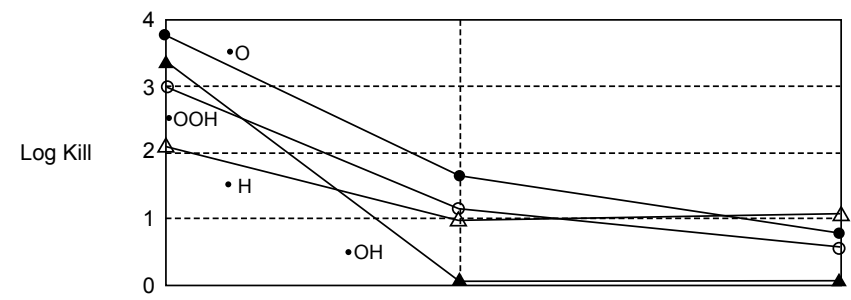

Figure 3: Comparison $\mathrm{OH}$ radical, $\mathrm{H}$ radical, $\mathrm{OOH}$ radical and $\mathrm{O}$ radical for bacteria inactivation.

The order is $\mathrm{OH}$ radical $>\mathrm{OOH}$ radical $>\mathrm{O}$ radical $>\mathrm{H}$ radical

*Corresponding author: Hideharu Shintani, Chuo University, School of Science 1-13-27, Kasuga Bunkyo 112-0003 Tokyo, Japan, Tel: +81425922336; E-mail: shintani@mail.hinocatv.ne.jp

Received January 28, 2013; Accepted May 20, 2013; Published May 23, 2013

Citation: Shintani H (2013) Whether Gas Plasma Exposure can Inactivate Virus in the Room in Success. Pharm Anal Acta 4: 236. doi:10.4172/2153-2435.1000236

Copyright: ( $) 2013$ Shintani H. This is an open-access article distributed under the terms of the Creative Commons Attribution License, which permits unrestricted use, distribution, and reproduction in any medium, provided the original author and source are credited. 


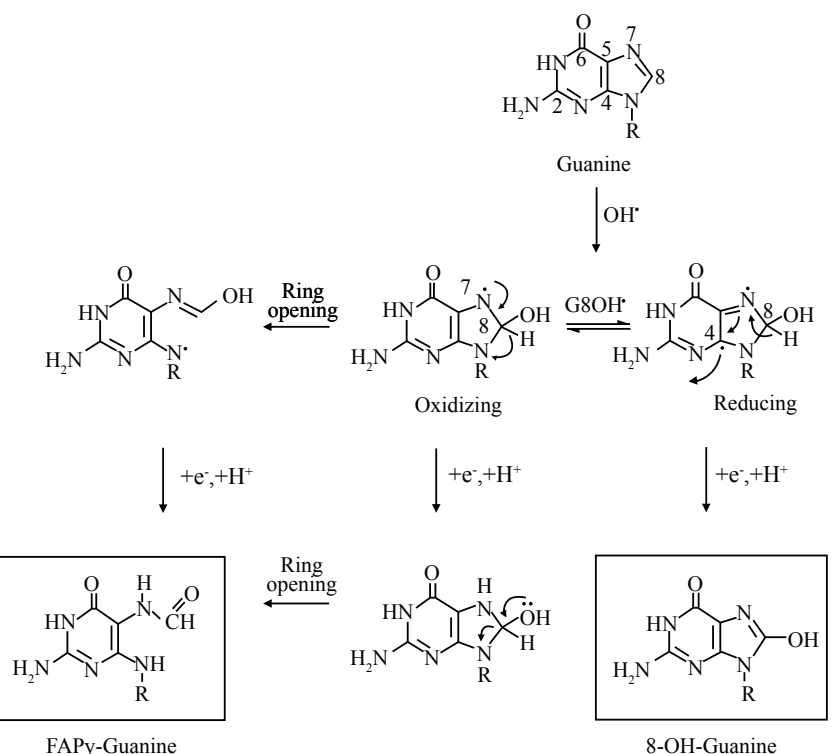

FAPy-Guanine and close ones bound to produce $\mathrm{H}_{2} \mathrm{O}_{2}$ and penetrate into bacteria and spore as $\mathrm{H}_{2} \mathrm{O}_{2}$ was neutral, then using the trace amount of $\mathrm{Fe}^{2+}$ or $\mathrm{Cu}^{+}$in bacteria and spores, $\mathrm{OH}$ radicals again produce within bacteria or spore and $\mathrm{OH}$ radicals destroy them. Destruction mechanism is following, $\mathrm{OH}$ radicals break hydrogen bonding in protein and nucleic acid. $\mathrm{OH}$ radical attack DNA and produce 8 OhdG (8 hydroxy guanine, Figure 4) as one example and inhibit correct hydrogen bonding formation, resulting in denaturation and inactivation of protein and DNA of bacteria and spore, respectively.

So finally we need to discuss about if virus can be inactivated by gas plasma exposure. Virus has no $\mathrm{Fe}^{2+}$ and $\mathrm{Cu}^{+}$. In that means even if $\mathrm{H}_{2} \mathrm{O}_{2}$ can penetrate into within virus, no Fenton reaction occurs, so inactivation of virus by $\mathrm{OH}$ radical was not occurred within virus. If occurred it was only by direct attacking of $\mathrm{OH}$ radicals. However, as already mentioned flight distance of $\mathrm{OH}$ radical is around 0.003 to $0.000003 \mathrm{~cm}$ during life period, so from this fact virus inactivation may not occur in real status.

From these considerations, we decided that Sharp Co. might not do PR based on correct experimental result.

\section{Reference}

1. Halliwelll B, Gutteridge J (2007) Free Radicals in Biology and Medicine. Oxford University Press. 